FEI-HUI HUANG, Ph.D.

E-mail: kiki_huangs@yahoo.com

Oriental Institute of Technology

Department of Marketing and Distribution Management

Sihchuan Rd., Banciao Dist., New Taipei City, 22061,

Taiwan, R.O.C.
Human-Transport Interaction Original Scientific Paper Submitted: 8 June 2018 Accepted: 24 June 2019

\title{
UNDERSTANDING USERS' EXPERIENCES OF RIDING A TWO-WHEELER VEHICLE AND THEIR INTENTIONS OF PURCHASING ELECTRIC TWO-WHEELERS
}

\begin{abstract}
More than 13.7 million people in Taiwan are scooter users, which signifies the highest density of scooter users in the world. The aim of the present study is to use the user experience $(U X)$ evaluation methods to investigate the factors that influence the users' satisfaction, recommendation intention, and willingness to accommodate Electric two-wheelers (E2Ws). An online survey design has been used to recruit two-wheeler owners who live in Taiwan. The results of the hierarchical multiple regression analysis, based on a sample of 315 Taiwanese, indicate that the variables of satisfaction, positive emotions, and riding experience predicted whether users intended to recommend a two-wheeler. The results also reveal that external motivation is the core factor that influences a rider's willingness to purchase an E2W. It highlights the importance of providing opportunities for people to experience the advantages of E2Ws and services. Having good hedonic and pragmatic experiences accumulated during two-wheeler usage may further positively influence the users' satisfaction and intrinsic motivation. It is recommended that the government and the related industries consider the above issues when formulating related policies or developing E2W or battery technologies.
\end{abstract}

\section{KEY WORDS}

electric two-wheelers; user experience evaluation; two-wheeler usage; interactions; motivation;

\section{INTRODUCTION}

Taiwan is an insular nation with a population of approximately 23 million people. The most commonly used method of road transport for the Taiwanese are scooters (45.9\%), followed by cars $(23.7 \%)$, buses (8.8\%), walking (7.1\%), and bicycles (4.1\%) [1]. One can see that the proportion of the Taiwanese riding two-wheelers is as high as $50 \%$. Among the Taiwanese, there are more than 13.7 million people who are scooter users, which reflects the highest density of scooter users in the world. Scooters that utilize fossil fuels in internal combustion engines emit tailpipe pollutants that may have a negative impact on human health. Two-wheeled vehicles with electric propulsion have received increasing attention because of their low carbon emissions, fuel independency, and environmental friendliness. Electric two-wheelers (E2Ws) also help with saving costs related to fuel, spark plug changes, and oil filter replacements; these facts, coupled with their minimalistic design characteristics, result in low maintenance costs. In Taiwan, E2Ws include electric scooters (e-scooters), small-scale e-scooters, electric bikes (e-bikes), and electric-assisted bicycles. According to the definition in the Taiwan's Chinese National Standards (CNS) for the E2Ws, e-scooters should be designed with a speed limit of over $45 \mathrm{~km} / \mathrm{h}$ on motor power alone on level ground and over 1,000 W output. The small-scale e-scooters should be designed with a speed limit of less than $45 \mathrm{~km} / \mathrm{h}$ and less than 1,000 W output. On the other hand, an e-bike is designed with a speed limit of less than $25 \mathrm{~km} / \mathrm{h}$. As for the electric-assisted bicycles, they should be designed with pedals and limited to a top speed of $25 \mathrm{~km} / \mathrm{h}$. In transportation engineering, speed is one of the basic variables that index the state and the level of service of roadway facilities. A reduction in the speed level leads to a safety improvement for all types of traffic accidents, including collision between motor vehicles, collision between a motor vehicle and a pedestrian or cyclist, and motor vehicles collision with a fixed obstacle at the roadside [2-4]. In order to improve air quality, road safety, and public health, the Taiwanese government is ramping up efforts to push for the adoption of E2Ws in the market. The global E2W market is segmented on the basis of regions into North America, Asia Pacific, Europe, and Rest of the World. Asia Pacific accounted for the largest share in 2017 , owing to the regional growth in vehicle charging infrastructure in emerging countries such as China and Taiwan [5]. In addition, e-bikes are one of the fastest growing segments of the global transport market with potential for disruptive impact on the existing mobility patterns $[6,7]$. However, as of the end of 2017, the market share of E2Ws as a percentage of the Taiwanese two-wheeler market was only $2.23 \%$, even though the Taiwanese government has continued providing special concessions or subsidies for the purchase of E2Ws, offering special 
incentives to the manufacturers, and has introduced several programs to establish a foundation for the development of E2Ws. This highlights the importance of discovering the motivations that will increase people's willingness to replace gas-powered scooters with E2Ws.

User Experience (UX) is an umbrella term for new ways of understanding and studying the quality-in-use of interactive products. Practitioners and researchers from a wide range of disciplines are working daily with this concept. ISO FDIS 9241-210 [8] defined UX as "a person's perceptions and responses that result from the use and/or anticipated use of a product, system or service." The UX is the result of the interaction between three elements: the user, the system, and the context [9]. The subjective nature of UX has two different time frames; user experience based on short-term usage and long-term usage. Examples of the best-known UX evaluation methods are AttrakDiff questionnaire [10] and User Experience Questionnaire (UEQ) [11]. Many user experience evaluation methods are not tailored for long-term evaluations. Experiences do not only consist of contextual details, but also of value-charged elements, such as emotions or overall evaluative judgments. One can distinguish two approaches to the reconstruction of value-charged experiences: the constructive and the value-account. The value-account, which stores the frequency and intensity of positive or negative responses to stimuli, is the existence of a memory structure [12]. Examples of methods designed for long-term evaluations are iScale [13] and UX Curve [14]. The above-mentioned questionnaire designs are worth referencing. Since value-account is more accessible and better retained over time than details from the episodic memory, it will actually cue episodic information when reconstructing an experience, or feed into a potential overall evaluation, even in the absence of any episodic information $[15,16]$. Therefore, the design of the self-reported quantitative ratings for the present study is based on the value-account approach and long-term usage, to gauge the UX of two-wheeler riders.

UX needs to be concerned with satisfying both pragmatic and hedonic goals of the users related to the experiences and outcomes of interactions [17, 18]. Pragmatic quality calls for a focus on the product - its utility and usability in relation to potential tasks. Usability is widely recognized as critical to the success of interactive systems or products [19, 20]. There exist a number of standardized usability questionnaires. Among them, the System Usability Scale (SUS) [21] provides a "quick and dirty" usability scale to evaluate practically any kind of system. It consists of a 10-item questionnaire with five response options for respondents, from strongly agree to strongly disagree. The SUS has been tried and tested throughout almost 30 years of use, and has proven to be a dependable method of evaluating the usability of systems compared to industry standards. In contrast, hedonic quality calls for a focus on the self, i.e. the question of why someone owns and uses a particular product [22]. All the designed products evoke a wide range of emotions, both negative and positive. These emotions provide the basic evaluation in terms of hedonic values, often causing the organism to be attracted to what it likes and to avoid what it does not like. Human-computer interaction $(\mathrm{HCl})$ work relates to the use of emotions and emotional displays in products that interact with the users. The ability of emotional behaviours to influence a person's emotional and motivational state could potentially, if exploited effectively, guide a user towards more effective interactions [23]. The OCC model of emotion proposed by Ortony, Clore, and Collins in 1988 [24] is a widely used model of emotion that states that the strength of a given emotion depends primarily on the events, agents, or objects in the environment of the agent exhibiting the emotion. The model specifies about 22 emotion categories and consists of five processes that define the complete system that characters follow, from the initial categorization of an event to the resulting behaviour of the character. These processes are: a) classifying the event, action, or object encountered; b) quantifying the intensity of affected emotions; c) the interaction of the newly generated emotion with the existing emotions; d) mapping the emotional state to an emotional expression; and e) expressing the emotional state. An advantage of the OCC model is that it distinguishes emotions in terms of their core situational meanings, which is both straightforward and reliable [25]. The present study is to gauge the users' long-term experiences. Therefore, the questionnaire respondents must have had more than one month of two-wheeler riding experience. This study will not discuss the emotions generated by prospective consequence and unfamiliar aspect. Fourteen emotions were chosen from OCC model to gauge hedonic experiences. Seven positive emotions are gloating, admiration, joy, satisfaction, pride, love, and happy-for and seven negative emotions are pity, reproach, distress, disappointment, shame, hate, and resentment. In addition, positive emotions stimulate product purchase intentions [26, 27], repurchase intentions [28], and product attachment [29]. In human product interactions, products can evoke emotions in various ways. The positive emotions may be evoked by the product, the meaning of the product, the interaction with the product, the activity that is facilitated by this interaction, themselves, and others involved in the interaction [30]. Adding these items to the hedonic quality subjective rating would facilitate identifying the sources of the emotions felt for riders. Therefore, the present study, in order to develop an instrument that reflects Taiwanese UX, included items associated with 
pragmatic quality, hedonic quality, and sources of the emotions felt that reflect Taiwanese UX, in addition to items that measured satisfaction and user intention.

The purpose of this study is to explore two-wheeler riders' opinions on UXs. An anonymous survey among the Taiwanese scooter users was conducted. The research uses insight in affect to capture the pleasurable consumer experience of using two-wheeler products in order to understand the factors that influence satisfaction and recommendation intention in light of the UX. More precisely, the acceptance of a two-wheeler product was examined, from the point of view of human-product interaction, based on the emotional response of the rider. Furthermore, a greater understanding of the factors that affect the adoption of an $\mathrm{E} 2 \mathrm{~W}$ is required in order to better understand and facilitate user acceptance.

\section{METHODS}

\section{Questionnaire development}

The survey was broadcast online from September to November 2017, on multiple advertisement channels. It recruited two-wheeler owners who lived in Taiwan. The questionnaire contained the following six sections: (1) Personal information: four items designed to collect socio-demographic data on gender, age, education, and region of residence; (2) Two-wheeler usage: four items designed to collect data on transportation usage (scooter, electric scooter, electric bike/moped, and bike), riding experience, two-wheeler usage (commuting, sports and leisure, shopping, dropping off/ picking up a child from school, and other), and reasons for owning the two-wheeler (speed, appearance, quiet ride, oil price, vehicle price, performance, environmental protection, comfort, future trends, social needs, work demands, recommendations from friends or family, convenience, government grant amount, safety, and other). Multiple answers were allowed for two-wheeler usage and reasons for ownership; (3) Pragmatic quality: ten items of SUS were used to measure subjective assessments of usability; (4) Hedonic quality: twenty-one items designed to measure the emotions felt (14 items) and sources of emotions (1 item). The emotions felt were assessed using a 5-point Likert scale, ranging from very much to very little. Seven basic sources of emotions evoked by the object, the meaning of the object, the interaction with the object, the activity that is facilitated by the interaction, themselves, others involved in the interaction [29], and social life were taken (multiple answers); (5) Satisfaction: two items were designed to collect quantitative data on satisfaction levels and willingness to recommend two-wheelers to people who are close to them, assessed using a 5-point Likert scale ranging from strongly agree to strongly disagree; (6) Intention: two items were designed to collect categorical data on user willingness to own an E2W (yes or no) and attitude towards the purchase of E2Ws (multiple answers).

\section{Participants}

A total of 336 questionnaires were collected, and 315 valid questionnaires were used for the analysis. Invalid questionnaires mainly resulted from incomplete answers. The overall response rate was $67.2 \%$ (336/500). The median age of respondents was 41 years (min:15, max:68), with $36.5 \%$ females $(n=115)$ and $63.5 \%$ males $(n=200)$. Their median riding experience was 8 years. The demographic information of the respondents is shown in Table 1.

Table 1 - Demographic information of the respondents

\begin{tabular}{|c|c|c|c|}
\hline \multicolumn{2}{|c|}{ Item } & Frequency & $\%$ \\
\hline \multirow{2}{*}{ Gender } & Female & 115 & 36.5 \\
\hline & Male & 200 & 63.5 \\
\hline \multirow{6}{*}{ Age } & $<20$ & 8 & 2.5 \\
\hline & $20-29$ & 59 & 18.7 \\
\hline & $30-39$ & 65 & 20.6 \\
\hline & $40-49$ & 125 & 39.7 \\
\hline & $50-59$ & 46 & 14.6 \\
\hline & $\geq 60$ & 12 & 3.8 \\
\hline \multirow{6}{*}{ Education } & Junior & 7 & 2.2 \\
\hline & Senior high & 58 & 18.4 \\
\hline & Junior college & 60 & 19 \\
\hline & University & 128 & 40.6 \\
\hline & Master & 50 & 15.9 \\
\hline & Ph.D. & 12 & 3.8 \\
\hline \multirow{4}{*}{$\begin{array}{l}\text { Transportation } \\
\text { usage }\end{array}$} & Scooter & 234 & 74.3 \\
\hline & Electric scooter & 13 & 4.1 \\
\hline & $\begin{array}{l}\text { Electric bike/ } \\
\text { moped }\end{array}$ & 21 & 6.7 \\
\hline & Bike & 47 & 14.9 \\
\hline
\end{tabular}

\section{Data analysis}

Analyses were conducted using SPSS software, Version 22.0. T tests, chi-square test, ANOVA, correlation analysis, and hierarchical multiple regression analysis were used to assess the variables. The twotailed significance level was set at $p<.05$.

\section{RESULTS}

In this study, the internal consistency of the emotions felt, pragmatic quality, and satisfaction scores were high (Cronbach's $\propto$ on the pooled values: emotions felt, $\propto=.865$; pragmatic quality, $\propto=.709$; satisfaction, $\propto=.755)$. The sampling for emotions felt 
(Kaiser-Meyer-Olkin (KMO) value=.929) and pragmatic quality (KMO value $=.766$ ) is adequate. The items on each variable were divided into two parts: positive and negative.

\subsection{Descriptive statistics}

The descriptive statistics of two-wheeler usage and the reasons for ownership are shown in Table 2.

Table 2 - Descriptive statistics of two-wheeler usage and reasons for ownership

\begin{tabular}{|c|c|c|c|}
\hline & Item & $\begin{array}{c}\text { Frequency } \\
(N)\end{array}$ & $\%$ \\
\hline \multirow{5}{*}{$\begin{array}{l}\text { Two-wheeler } \\
\text { usage }\end{array}$} & Commuting & 271 & 41.3 \\
\hline & Sports and leisure & 146 & 22.3 \\
\hline & Shopping & 145 & 22.1 \\
\hline & Picking up a child & 83 & 12.7 \\
\hline & Other & 11 & 1.7 \\
\hline \multirow{16}{*}{$\begin{array}{l}\text { Reasons for } \\
\text { ownership }\end{array}$} & Convenience & 232 & 25.8 \\
\hline & Work demands & 124 & 13.8 \\
\hline & Vehicle price & 100 & 11.1 \\
\hline & Comfort & 72 & 8 \\
\hline & Performance & 68 & 7.6 \\
\hline & Speed & 56 & 6.2 \\
\hline & Environment & 53 & 5.9 \\
\hline & Oil price & 34 & 3.8 \\
\hline & Safety & 32 & 3.6 \\
\hline & Social needs & 31 & 3.4 \\
\hline & Recommendations & 22 & 2.4 \\
\hline & Appearance & 20 & 2.2 \\
\hline & Government grant & 19 & 2.1 \\
\hline & Quiet ride & 16 & 1.8 \\
\hline & Future trends & 15 & 1.7 \\
\hline & Other & 6 & 0.7 \\
\hline
\end{tabular}

Most of the agreement levels related to SUS $(\bar{X}=68.42, \sigma=12.02)$, satisfaction $(\bar{X}=3.96, \sigma=0.86)$, and recommendation intention $(\bar{X}=3.54, \sigma=0.91)$ were slightly agreed. The average positive emotions rating was $3.57(\mathrm{SD}=1.03)$, while the negative emotions rating was $2.0(\mathrm{SD}=0.95)$. The data on SUS and emotions felt are shown in Table 3 and Table 4, respectively. In addition, approximately 241 respondents (76.5\%) were willing to purchase an E2W, while 74 respondents were unwilling to purchase one. The reasons for their willingness or unwillingness to purchase an E2W are shown in Table 5.

\subsection{T-test}

The T-test results indicated that the SUS of "I would imagine that most people would learn to use this system very quickly" ( $t=-2.16, p<.05)$ and emotions felt of pity $(t=2.68, p<01)$, reproach $(t=2.26$, $p<.05)$, disappointment $(t=2.12, p<.05)$, and shame $(t=2.28, p<.05)$ differed significantly by gender (please refer to Table 6 for the respective data).

\subsection{Chi-Square Test}

The chi-square test results indicated that purchase intention differed significantly according to transportation usage $\left[\chi_{(3)}^{2}=9.99, p=0.019\right]$. Respondents who were e-bike riders $(6.3 \%$; $A R=2.6)$ showed a higher purchase intention percentage relative to bicycle riders (10.2\%; AR=-1.5).

Reasons for owning a two-wheeler differed significantly according to age $\left[\chi_{(75)}^{2}=358.96, p=0.000\right]$. Respondents aged 50-59 displayed a higher percentage of social needs $(40 \%$; $A R=4.7)$, friends or family recommendations (35.5\%; $A R=3.6)$, quiet (73.3\%; $A R=6.8$ ), and government grant (82.1\%; $\mathrm{AR}=12.9)$ relative to those aged $40-49(7.7 \%-22.6 \%$;

Table 3 - Descriptive statistics of SUS

\begin{tabular}{|c|c|c|c|c|c|}
\hline Item & $\begin{array}{l}\text { Agree strongly } \\
{[\%]}\end{array}$ & $\begin{array}{c}\text { Agree } \\
{[\%]}\end{array}$ & $\begin{array}{c}\text { Neutral } \\
{[\%]}\end{array}$ & $\begin{array}{c}\text { Disagree } \\
{[\%]}\end{array}$ & $\begin{array}{c}\text { Disagree strongly } \\
{[\%]}\end{array}$ \\
\hline I like to ride my two-wheeler frequently & 60.6 & 27.3 & 9.1 & 0 & 3 \\
\hline I found my two-wheeler unnecessarily complex & 3 & 15.2 & 36.4 & 36.4 & 9.1 \\
\hline I thought my two-wheeler was easy to ride & 57.6 & 27.3 & 15.2 & 0 & 0 \\
\hline $\begin{array}{l}\text { I need the support of a technical person to be able } \\
\text { to use my two-wheeler }\end{array}$ & 6.1 & 21.2 & 33.3 & 30.3 & 9.1 \\
\hline $\begin{array}{l}\text { I found the various functions in my two-wheeler } \\
\text { were well integrated }\end{array}$ & 39.4 & 36.4 & 18.2 & 6.1 & 0 \\
\hline I thought my two-wheeler was too inconsistent & 9.1 & 18.2 & 36.4 & 27.3 & 9.1 \\
\hline $\begin{array}{l}\text { I would imagine that most people would learn to } \\
\text { use my two-wheeler very quickly }\end{array}$ & 51.5 & 36.4 & 12.1 & 0 & 0 \\
\hline I found my two-wheeler very cumbersome to use & 0 & 6.1 & 30.3 & 42.4 & 21.2 \\
\hline I felt very confident using my two-wheeler & 69.7 & 21.2 & 9.1 & 0 & 0 \\
\hline $\begin{array}{l}\text { I needed to learn a lot of things before I could get } \\
\text { going with my two-wheeler }\end{array}$ & 3 & 12.1 & 30.3 & 30.3 & 24.2 \\
\hline
\end{tabular}


Huang F-H. Understanding Users' Experiences of Riding a Two-Wheeler Vehicle and their Intentions of Purchasing Electric Two-Wheelers

Table 4 - Descriptive statistics of emotions felt

\begin{tabular}{|c|c|c|c|c|c|c|}
\hline \multicolumn{2}{|c|}{ Emotions } & Very little [\%] & Little [\%] & Moderate [\%] & Much [\%] & Very much [\%] \\
\hline \multirow{7}{*}{$\begin{array}{l}\text { Positive } \\
\text { emotions }\end{array}$} & Gloating & 6.1 & 9.1 & 15.2 & 30.3 & 39.4 \\
\hline & Admiration & 6.1 & 9.1 & 18.2 & 18.2 & 48.5 \\
\hline & Joy & 0 & 3 & 21.2 & 18.2 & 57.6 \\
\hline & Satisfaction & 3 & 3 & 18.2 & 24.2 & 51.5 \\
\hline & Pride & 0 & 3 & 27.3 & 18.2 & 51.5 \\
\hline & Love & 3 & 0 & 21.2 & 18.2 & 57.6 \\
\hline & Happy-for & 3 & 3 & 21.2 & 18.2 & 54.5 \\
\hline \multirow{7}{*}{$\begin{array}{l}\text { Negative } \\
\text { emotions }\end{array}$} & Pity & 30.3 & 39.4 & 27.3 & 3 & 0 \\
\hline & Reproach & 33.3 & 33.3 & 30.3 & 3 & 0 \\
\hline & Distress & 27.3 & 39.4 & 27.3 & 3 & 3 \\
\hline & Disappointment & 39.4 & 33.3 & 24.2 & 3 & 0 \\
\hline & Shame & 33.3 & 42.4 & 21.2 & 3 & 0 \\
\hline & Hate & 36.4 & 36.4 & 24.2 & 3 & 0 \\
\hline & Resentment & 24.2 & 45.5 & 27.3 & 3 & 0 \\
\hline
\end{tabular}

Table 5 - Descriptive statistics of reasons for willing or unwilling to purchase an $E 2 \mathrm{~W}$

\begin{tabular}{|c|c|c|c|c|c|}
\hline \multicolumn{3}{|c|}{ Reasons for willing to buy an E2W } & \multicolumn{3}{|c|}{ Reasons for unwilling to buy E2W } \\
\hline Items & Frequency $(N)$ & $\%$ & Items & Frequency $(N)$ & $\%$ \\
\hline Environment & 125 & 15.3 & Vehicle price & 39 & 18.6 \\
\hline Convenience & 109 & 13.4 & Convenience & 34 & 16.2 \\
\hline Vehicle price & 79 & 9.7 & Performance & 25 & 11.9 \\
\hline Government grant & 76 & 9.3 & Safety & 19 & 9.0 \\
\hline Oil price & 71 & 8.7 & Work demands & 15 & 7.1 \\
\hline Quiet ride & 59 & 7.2 & Oil price & 13 & 6.2 \\
\hline Comfort & 52 & 6.4 & Comfort & 12 & 5.7 \\
\hline Future trends & 47 & 5.8 & Speed & 12 & 5.7 \\
\hline Performance & 45 & 5.5 & Future trends & 11 & 5.2 \\
\hline Safety & 41 & 5.0 & Government grant & 8 & 3.8 \\
\hline Speed & 40 & 4.9 & Other & 6 & 2.9 \\
\hline Work demands & 32 & 3.9 & Environment & 4 & 1.9 \\
\hline Appearance & 16 & 2.0 & Quiet ride & 4 & 1.9 \\
\hline Social needs & 13 & 1.6 & Appearance & 4 & 1.9 \\
\hline Recommendations & 8 & 1.0 & Social needs & 2 & 1.0 \\
\hline Other & 2 & 0.2 & Recommendations & 2 & 1.0 \\
\hline
\end{tabular}

Table 6 - Means and standard deviations of emotions felt and SUS factors by gender

\begin{tabular}{|c|c|c|c|c|c|c|}
\hline \multicolumn{2}{|c|}{ Items } & Gender & Mean & SD & t-value & Sig. \\
\hline \multirow{8}{*}{ Emotions felt } & \multirow{2}{*}{ Pity } & Female & 1.82 & 0.86 & 2.68 & 0.008 \\
\hline & & Male & 2.11 & 0.99 & & \\
\hline & \multirow{2}{*}{ Reproach } & Female & 1.90 & 0.89 & 2.26 & 0.025 \\
\hline & & Male & 2.15 & 0.99 & & \\
\hline & \multirow{2}{*}{ Disappointment } & Female & 1.87 & 0.84 & 2.12 & 0.039 \\
\hline & & Male & 2.09 & 1.01 & & \\
\hline & \multirow{2}{*}{ Shame } & Female & 1.77 & 0.82 & 2.28 & 0.024 \\
\hline & & Male & 2.01 & 0.95 & & \\
\hline \multirow{2}{*}{ SUS } & \multirow{2}{*}{ Easy to learn } & Female & 2.72 & 0.88 & -2.158 & 0.032 \\
\hline & & Male & 2.74 & 1.05 & & \\
\hline
\end{tabular}


$\mathrm{AR}=-1.8-$-4.0). In contrast, respondents aged 40-49 displayed a higher percentage of vehicle price $(47.5 \%$; $A R=1.9)$ and work demands (48.4\%; $A R=2.3)$ relative to those aged 50-59 (0\%; AR=-3.8- -4.2). Respondents aged 40-49 displayed a lower percentage of appearance $(10.0 \%$; $A R=-2.6)$ relative to those aged under 20 (10.0\%; AR=3.4) and 20-29 (45.0\%; AR=2.6).

Reasons for purchasing an E2W differed significantly according to purchase intention [ $\chi_{(15)}^{2}=$ 84.22, $p=0.00]$. Respondents with purchase intention displayed a higher percentage of quiet ride $(5.7 \%$; $A R=2.8)$, government grant $(7.5 \%$; $A R=2.6)$, and environmental protection $(12.1 \% ; A R=5.2)$ relative to those with no purchase intention. In contrast, respondents with no purchase intention displayed a higher percentage of vehicle price (3.8\%; $A R=3.5)$, performance (2.4\%; $A R=3.2)$, and other $(0.6 \% ; A R=3.8)$ relative to those with purchase intention.

Reasons for willingness or unwillingness to purchase an E2W differed significantly according to region of residence [ $\left.\chi_{(45)}^{2}=72.81, p=0.005\right]$. Respondents who lived in eastern Taiwan displayed a higher percentage of friends or family recommendations (14.3\%; $\mathrm{AR}=5.9$ ) relative to those who lived in northern Taiwan (57.1\%; AR=-1.5) and southern Taiwan (0\%; AR=-0.5).

\subsection{ANOVA}

The results of a one-way analysis of variance (ANOVA) indicated that the mean difference of recommendation intention $[F(3,311)=9.713, p=0.000]$, satisfaction level $[F(3,311)=3.317, p=0.020]$, and SUS scores $[F(3,311)=2.876, p=0.036]$ among different transportation usages were significant. Scheffe's post hoc test revealed that the respondents who were e-bike riders showed higher SUS scores $(\bar{X}=74.75$, $\sigma=14)$ than those who were bicycle riders ( $\bar{X}=65.43$, $\sigma=10.61)$. Moreover, e-bike riders had higher satisfaction levels $\left(\bar{X}=4.5, \sum=0.69\right)$ than scooter riders
$(\bar{X}=3.92, \sigma=0.85)$. Inaddition, therespondentswhowere e-bike riders had higher recommendation intentions $(\bar{X}=4.45, \sigma=0.69)$ than those who were scooter riders $(\bar{X}=3.43, \sigma=0.86)$ or bicycle riders $(\bar{X}=3.64, \sigma=0.97)$ $(p<0.05)$.

\subsection{Correlation analysis}

The correlation analytical results showed that positive emotions were positively correlated with SUS scores and satisfaction, while negative emotions were negatively correlated with SUS scores and satisfaction. Moreover, SUS score was positively correlated with satisfaction. More specifically, joy and happy-for emotions were positively evoked by two-wheelers. Joy, pride, love, happy-for, and distress emotions were positively evoked by interactions with two-wheelers. Gloating, admiration, joy, pride, and happy-for emotions were positively evoked by social life; in contrast, hate emotion was negatively evoked by others involved in the interaction. In addition, riding experience was negatively correlated with positive emotions, including gloating, joy, pride, love, and reason for owning a two-wheeler, including future trends $(r=-0.13)$, friends or family recommendations ( $r=-0.13)$, and environmental protection $(r=-0.26)$. The final model of the relationship among the above-mentioned variables is shown in Figure 1. Furthermore, riding experience was positively correlated with dropping off/picking up a child from school $(r=0.18)$, convenience $(r=0.16)$, and work demands $(r=0.29)$.

\subsection{Hierarchical multiple regression analysis}

Hierarchical multiple regression analysis was used to predict recommendation intention $(Y)$ from the survey data. Variables were entered in three steps: (1) the predictor variables (personal information, two-wheeler usage, pragmatic quality, positive emotions, negative

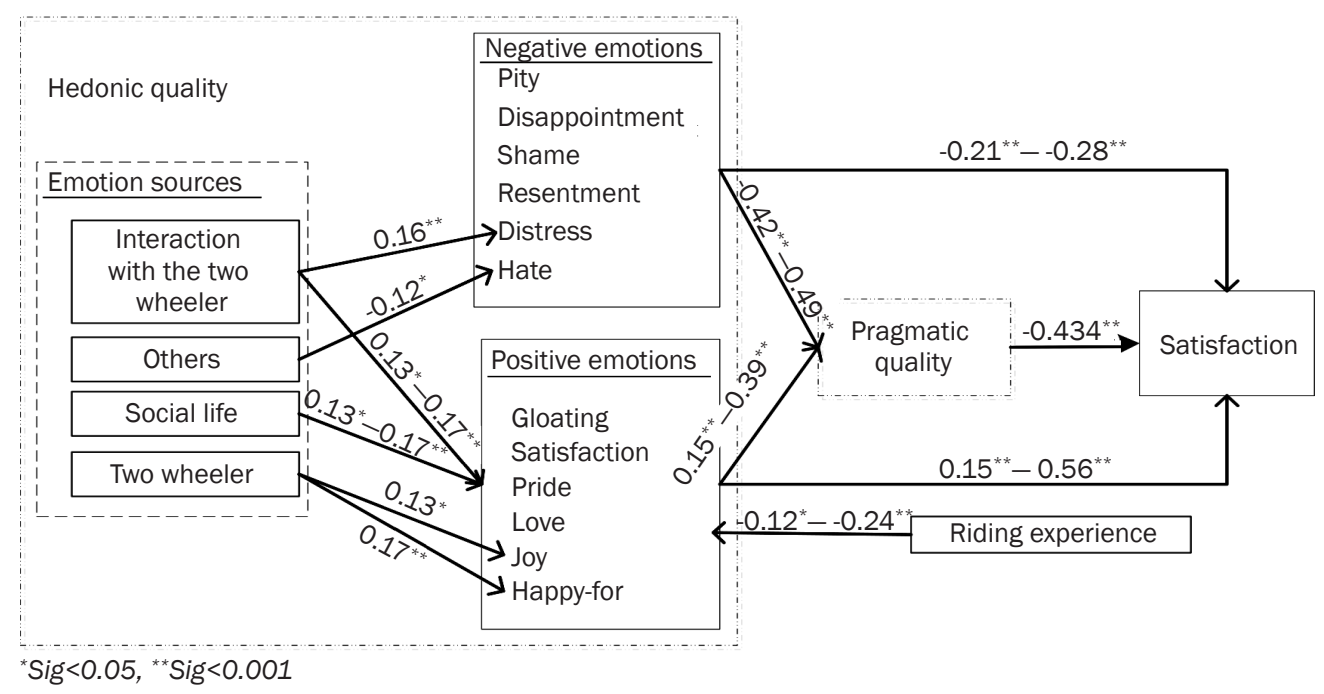

Figure 1 - Final model of the relation among emotion sources, emotions felt, riding experience, SUS score, and satisfaction 
Table 7 - Hierarchical multiple regression results for intention to recommend their own two-wheeler (Y)

\begin{tabular}{|c|c|c|c|c|c|}
\hline & \multirow{2}{*}{ Step } & Step 1 & Step 2 & \multirow{2}{*}{$R^{2}$} & \multirow{2}{*}{$\Delta R^{2}$} \\
\hline & & $\beta$ & $\beta$ & & \\
\hline \multirow[t]{5}{*}{1} & $\begin{array}{l}\text { Two-wheeler usage } \\
\text { Commuting } \\
\text { Sports and leisure } \\
\text { Shopping } \\
\text { Picking up a child } \\
\text { Other }\end{array}$ & $\begin{array}{c}-0.011 \\
0.051 \\
0.179^{\star} \\
-0.083 \\
0.367\end{array}$ & $\begin{array}{c}-0.005 \\
0.098 \\
0.186^{\star} \\
-0.066 \\
0.355\end{array}$ & 0.452 & $0.436^{* * *}$ \\
\hline & SUS & -0.001 & -0.001 & & \\
\hline & Positive emotions & $0.353^{* * *}$ & $0.332^{* * *}$ & & \\
\hline & Negative emotions & -0.041 & -0.046 & & \\
\hline & Satisfaction & $0.441^{* * *}$ & $0.444^{* * *}$ & & \\
\hline \multirow{5}{*}{2} & Age & & 0.020 & 0.470 & 0.009 \\
\hline & Gender & & 0.045 & & \\
\hline & Education & & -0.035 & & \\
\hline & Region of residence & & 0.013 & & \\
\hline & Riding experience & & $-0.013^{* *}$ & & \\
\hline
\end{tabular}

${ }^{\star} p<0.05 ;{ }^{\star \star} p<0.01 ;{ }^{* \star \star} p<0.001$

emotions, and satisfaction); (2) the moderator variables (age, gender, education, region of residence, and riding experience); and (3) the interaction terms for moderation analysis. Results indicate that none of the predicted moderated relationships reached significance for $Y$. Table 7 represents the main predictor variables (excluding interactions) for $Y$. Among these, satisfaction, positive emotions, shopping, and riding experience significantly influenced the intention to recommend their own two-wheeler.

\section{DISCUSSION}

The major reason why respondents owned a two-wheeler was convenience, followed by commuting, price, comfort, and performance. The differences by age were found in other reasons for ownership. The secondary reason, in young adulthood (aged under 29), to purchase a two-wheeler focused on self-expression, while middle-aged people paid more attention to social needs, quiet ride, government grant, and friends' recommendations.

Most of the respondents were slightly satisfied with their two-wheelers. The results revealed that both hedonic and pragmatic qualities were important factors that influence the two-wheeler riders' satisfaction. The results of hedonic quality revealed that two-wheeler design and usage can mildly evoke positive emotions and low negative emotions. Emotions can serve as background factors that influence behavioural, normative and/or control beliefs. Compared to people in state of negative mood, the people in positive mood tend to evaluate events (such as the consequences of a behaviour) more favourably and to judge favourable events as more likely to occur [31-33]. The results found that the intensity of positive emotions for the respondents riding two-wheelers were slightly higher than those of negative emotions.

Regarding respondents' negative emotions felt, the highest rating was 2.06 for the "Reproach" category, followed by "Distress" (2.05), "Disappointment" (2.01), "Pity" (2.00), and "Hate" (1.99). Among them, the distress emotions showed low positive correlation with interaction with the two-wheeler, and hate emotions displayed low negative correlation with others involved in the interaction. Regarding the respondents' positive emotions felt, the highest rating was 3.84 for the "Satisfaction" category, followed by "Love" (3.8), "Happy-for" (3.78), "Joy" (3.78), and "Pride" (3.45). Positive emotions showed low positive correlations with two-wheeler product interaction, and respondent's social life. However, the rider's riding experience exhibited low negative correlations with positive emotions. That means that the riders with more years of riding experience felt lower positive emotions. Summarizing the results of hedonic quality, interacting with the two-wheeler plays an important role in influencing rider's emotions, both negative and positive. In two-wheelers, good quality/design beauty and enhancing social life have been found to be important factors that may have positive impact on the rider's positive emotions. Moreover, friends or family members who pay attention to and care about the rider's safety may reduce their negative emotions. Therefore, the product design and interpersonal interaction are important factors that influence the hedonic quality. In addition, the results of pragmatic quality revealed an average SUS score of 68.42 . That means that the two-wheeler design may provide a mildly pragmatic quality to riders. Here, pragmatic quality exhibited a moderate positive correlation with hedonic quality. Furthermore, gender differences were found in the SUS. Male riders 
tended to have higher agreement with the item of "I would imagine that most people would learn to use this system very quickly" than females. However, male riders tended to feel higher negative emotions than females. This means that two-wheeler designs do not meet male riders' expectations about what the experience would be like, which can negatively influence the emotions felt. The results showed that riding a two-wheeler can make some riders feel distress emotions. Many people find it difficult to put distressing thoughts out of their minds and may therefore cumulate anxiety [34]. Worry, anxiety, and insecurity emotions reflect uncertainty about the event outcome $[35,36]$. In other words, finding the reason for distress emotions in riders is one of the important ways of improving the pragmatic quality. In addition, the two-wheeler design should meet the needs of male riders for reducing negative emotions felt and increasing their satisfaction.

The core factors that influenced the recommendation intention were satisfaction, positive emotions, and riding experience. The riding experience displayed low positive correlation with the needs of dropping off/ picking up a child from school, convenience, and work demands. In other words, good hedonic and pragmatic qualities accumulated during two-wheeler usage may further positively affect the rider satisfaction. Emotions can have indirect effects on intentions and behaviour by influencing the kinds of beliefs that are salient in a given situation [34]. Design and service may continue to meet the riders' practical needs for different genders and different stages of two-wheeler usage that may further positively affect their recommendation intention. Comparing different two-wheelers, e-bike riders have significantly higher recommendation intentions than bicycle or scooter riders. This means that e-bikes can provide good design and service to the target market.

With regard to purchase intention, approximately $76.5 \%$ of the respondents were willing to purchase an E2W. The E2W rider's repurchase intention is as high as 97\%. Results revealed that two-wheeler UX is not a factor that influences his/her willingness to purchase an E2W. It means that the market potential of E2Ws is high. Government and related industries should provide opportunities for people to experience the advantages of E2Ws and services, because it is expected to stimulate E2W market share effectively. The core factors found in this study were driven by external motivation. Results showed that the major reason that respondents purchased an E2W was environmental protection, followed by convenience, vehicle price, and government grants. This result highlights the importance of government grants and establishing public awareness of environmental protection. In addition, the factors of vehicle price, performance, and others explain why approximately $23.5 \%$ of the respondents were unwilling to purchase an E2W. Since the
Taiwan E2W market is relatively immature, prices are still somewhat at a premium, and the infrastructure in place for charging is insufficient. Compared with the mature Taiwan scooter or bicycle market, E2Ws have no competitive advantage in price or performance. Moreover, current battery technology does not allow for charging in less than half an hour. In terms of current industry development, battery swap stations, analogous to gas stations, where refuelling can be completed in a few minutes is one of the solutions to address battery limitations [37-40]. In Taiwan, several battery-swapping systems for E2Ws have been established. The government and related industries should continue to invest in the development of E2Ws and new battery materials, and actively establish public awareness of the correct products and services for E2Ws, to increase the public acceptance of E2Ws.

\section{CONCLUSION}

The main aim of this study was to use UX evaluation methods to investigate the factors of two-wheeler usage, pragmatic quality, and hedonic quality that influence the riders' satisfaction, recommendation intentions, and willingness to accommodate E2Ws. The results of the survey conducted with two-wheeler commuters in Taiwan provide evidence of the evaluation methods for increasing the understanding of the experience of riding two-wheelers, and acceptance of E2Ws. In particular, user-perceived hedonic quality and pragmatic quality of two-wheelers play a big part in their satisfaction and recommendation intention, while riding experience, two-wheeler interactions, two-wheeler designs, and interpersonal interactions all appear to be important factors. In addition, external motivation plays a big part in driving the intention to purchase an E2W, while convenience, awareness of environmental concerns, government grants, vehicle price, performance, and charging services all appear to be important factors. It is to be hoped that, in order to increase the penetration level of E2Ws and improve air quality, road safety, and public health, the government and related industries will consider the above issues when formulating related policies or developing E2W or battery technologies.

\section{黃斐慧, 博士}

電子信箱: kiki_huangs@yahoo.com

亞東技術學院 行銷與流通管理系, 板橋市, 新北市, 台 灣

\section{民眾騎乘二輪車的使用者經驗是否影響他們未來購} 買電動二輪車意圖之探討

\section{摘要}

臺灣是世界上機車用戶密度最高的海島型國家，共有 超過1370萬民眾以機車為主要的代步工具。本研究目的 
以使用者經驗為評估技術，透過線上問卷調查方法取得影 響臺灣二輪車 (包括機車、自行車) 車主騎乘滿意度、推薦 產品意圖、以及電動二輪車選購意願的因素。應用分層多 元迴歸分析315份有效樣本的回饋資料, 結果顯示二輪車 騎乘滿意度、正向情緒、以及騎乘經驗為預測車主是否有 推薦二輪車給親朋好友意圖的重要變項。外部動機則為影 響民眾購買電動二輪車意願的關鍵因素，亦即表示，提供 民眾體驗電動二輪車騎乘及相關服務將可驅使他們考慮選 購相關產品。此外, 騎乘二輪車的享樂和實用經驗, 將積 極地影響民眾對二輪車的滿意度和內在動機。建議政府 及相關產業於訂定相關政策或開發電動二輪車或電池技術 時, 應考慮本研究所提出的考量因素。

\section{關鍵詞}

電動二輪車；使用者經驗評估；二輪車使用經驗；互動； 動機

\section{REFERENCES}

[1] MOTC (Ministry of Transportation and Communications). An Survey of the Daily Use of Vehicles; 2016. Available from: ///C:/Users/user/Downloads/105\%E 5\%B9\%B4\%E6\%91\%98\%E8\%A6\%81\%E5\%88\%86\%E $6 \% 9 E \% 90 . p d f$ [cited 8 Jan 18].

[2] OECD, European Conference of Ministers of Transport. Road Safety: Speed Moderation. Paris, France: Organization for Economic Co-operation and Development (OECD) Publications Service; 1996.

[3] Nilsson G. Traffic safety dimensions and the power model to describe the effect of speed on safety. PhD Thesis. Lund Institute of Technology; 2004.

[4] National Research Council. Highway Safety Manual. Washington, DC: American Association of State Highway and Transportation Officials; 2010.

[5] Half-Cooked Research Reports. Electric two-wheeler Market Research Report - Forecast 2023. ID: MRFR/ AM/4010-HCRR, 2018.

[6] Fishman E, Schepers P. Global bike share: what the data tells us about road safety. Journal of Safety Research. 2016;56: 41-45.

[7] Jones T, Harms L, Heinen E. Motives, perceptions and experiences of electric bicycle owners and implications for health, wellbeing and mobility. Journal of Transport Geography. 2016;53: 41-49.

[8] ISO IDS 9241-210. Ergonomics of human system interaction - Part 210: Human-centred design for interactive systems (formerly known as 13407). Geneva, Switzerland: International Organization for Standardization (ISO); 2010.

[9] Roto V, Law E, Vermeeren A, Hoonhout J (eds.). User experience white paper: Bringing clarity to the concept of user experience; 2011. Available from: http://www. allaboutux.org/uxwhitepaper [cited 12 Dec 17].

[10] Hassenzahl M, Burmester M, Koller F. AttrakDiff: Ein Fragebogen zur Messung wahrgenommener hedonischer und pragmatischer Qualität. In: Ziegler J, SzwilIus G. (eds.) Mensch \& Computer 2003, Interaktion in Bewegung. Sttutgart, Leipzig: Vieweg+Teubner Verlag; 2003: p. 187-196.

[11] Laugwitz B, Held T, Schrepp M. Construction and evaluation of a user experience questionnaire. In: Holzinger A. (ed.) $\mathrm{HCl}$ and Usability for Education and Work. USAB 2008. Lecture Notes in Computer Science, vol
5298. Berlin, Heidelberg: Springer; 2008. p. 63-76.

[12] Betsch T, Plessner H, Schwieren C, Gütig R. I like it but I don't know why: A value-account approach to implicit attitude formation. Personality and Social Psychology Bulletin. 2001;27(2): 242-253.

[13] Karapanos E, Martens JB, Hassenzahl M. Reconstructing experiences with iScale. International Journal of Human-Computer Studies. 2012;70(11): 849-865.

[14] Kujala S, Roto V, Väänänen-Vainio-Mattila K, Karapanos E, Sinnelä A. UX Curve: A method for evaluating long-term user experience. Interacting with Computers. 2011;23(5): 473-483.

[15] Koriat A, Goldsmith M, Pansky A. Toward a psychology of memory accuracy. Annual Review of Psychology. 2000;51(1): 481-537.

[16] Neisser U. John Dean's memory: A case study. Cognition. 1981;9(1): 1-22.

[17] Hassenzahl M. The interplay of beauty, goodness, and usability in interactive products. Human-Computer Interaction. 2004;19(4): 319-349.

[18] Bevan N. Classifying and selecting UX and usability measures. In: International Workshop on Meaningful Measures: Valid Useful User Experience Measurement; 2008. p. 13-18.

[19] Shackel B. Usability-context, framework, definition, design and evaluation. In: Shackel B, Richardson SJ. (Eds.) Human Factors for Informatics Usability. Cambridge: Cambridge University Press; 1991. p. 21-37.

[20] ISO 9241-11. Ergonomic requirements for Office Work with Visual Display Terminals (VDTs), Part 11: Guidelines for Specifying and Measuring Usability. Geneva, Switzerland: International Organization for Standardization; 1997.

[21] Brooke J. SUS-A quick and dirty usability scale. Usability Evaluation in Industry. 1996;189(194): 4-7.

[22] Hassenzahl M. User experience (UX): towards an experiential perspective on product quality. In: Proceedings of the $20^{\text {th }}$ Conference on I'Interaction Homme-Machine. ACM; 2008. p. 11-15.

[23] Marsella S, Gratch J, Petta P. Computational models of emotion. A Blueprint for Affective Computing A Sourcebook and Manual. 2010;11(1): 21-46.

[24] Ortony A, Clore GL, Collins A. The Cognitive Structure of Emotions. Cambridge, UK: Cambridge University Press; 1988

[25] Lazarus RS, Lazarus RS. Emotion and adaptation. Oxford University Press on Demand; 1991.

[26] Pham MT. Representativeness, relevance, and the use of feelings in decision making. Journal of Consumer Research. 1998;25(2): 144-159.

[27] Bitner MJ. Servicescapes: The impact of physical surroundings on customers and employees. Journal of Marketing. 1992;56(2): 57-71.

[28] Westbrook RA, Oliver RL. The dimensionality of consumption emotion patterns and consumer satisfaction. Journal of Consumer Research. 1991;18(1): 84-91.

[29] Mugge R, Schoormans JPL, Schifferstein HNJ. Design strategies to postpone consumers' product replacement. The value of a strong person-product relationship. The Design Journal. 2005;8(2): 38-48.

[30] Desmet PM. Faces of product pleasure: 25 positive emotions in human-product interactions. International Journal of Design. 2012;6(2): 1-29. 
[31] Forgas JP, Bower GH, Krantz SE. The influence of mood on perceptions of social interactions. Journal of Experimental Social Psychology. 1984;20: 497-513.

[32] Johnson EJ, Tversky A. Affect, generalization, and the perception of risk. Journal of Personality and Social Psychology. 1983;45: 20-31.

[33] Schaller M, Cialdini RB. Happiness, sadness, and helping: A motivational integration. In: Higgins ET, Sorrentino RM. (Eds.) Handbook of motivation and cognition: Foundations of social behavior. Vol. 2. New York, NY: Guilford Press; 1990. p. 265-296.

[34] Ajzen I. The theory of planned behaviour: reactions and reflections. 2011.

[35] Ellsworth PC. Some implications of cognitive appraisal theories of emotion. In: Strongman KT. (Ed.) International Review of Studies on Emotion. New York: Wiley; 1991. p. 143-162.
[36] Frijda NH. The emotions. Cambridge: Cambridge University Press; 1986.

[37] Li JQ. Transit bus scheduling with limited energy. Transportation Science. 2013;48(4): 521-539.

[38] Liu J. Electric vehicle charging infrastructure assignment and power grid impacts assessment in Beijing. Energy Policy. 2012;51: 544-557.

[39] Worley O, Klabjan D. Optimization of battery charging and purchasing at electric vehicle battery swap stations. In: 2011 IEEE Vehicle Power and Propulsion Conference (VPPC), 6-9 Sep 2011, Chicago, IL, USA. IEEE; 2011. p. 1-4.

[40] Lombardi P, Heuer M, Styczynski Z. Battery switch station as storage system in an autonomous power system: Optimization issue. In: IEEE Power and Energy Society General Meeting, 25-29 July 2010, Providence, RI, USA. IEEE; 2010. p. 1-6. 